\title{
Response of nitrogen dynamics in semi-natural and agricultural grassland soils to experimental variation in tide and salinity
}

\author{
A. Martijn Antheunisse $\cdot$ Roos Loeb · \\ Marzia Miletto • Leon P. M. Lamers • \\ Hendrikus J. Laanbroek $\cdot$ Jos T. A. Verhoeven
}

Received: 9 August 2006/ Accepted: 11 January 2007/ Published online: 16 February 2007

(C) Springer Science+Business Media B.V. 2007

\begin{abstract}
In the framework of rehabilitation efforts to enhance the ecological value of closed-off estuaries, we studied the effects of restoring a tidal movement and seawater incursion on soil nitrogen conversion rates and vegetation response of semi-natural and agricultural grasslands in an outdoor mesocosm experiment. Intact soil monoliths including vegetation were collected in June 2004 on two locations on the shores of the Haringvliet lagoon in the southwestern part of the Netherlands, which used to be a well-developed estuary before closure in 1970 . For more than 1 year, soil monoliths were
\end{abstract}

A. M. Antheunisse $(\bowtie) \cdot$ H. J. Laanbroek .

J. T. A. Verhoeven

Landscape Ecology, Institute of Environmental

Biology, Utrecht University, P.O. Box 800.84, 3508

TB Utrecht, The Netherlands

e-mail: a.m.antheunisse@bio.uu.nl

R. Loeb · L. P. M. Lamers

Department of Aquatic Ecology \& Environmental Biology, Institute for Water and Wetland Research, Radboud University Nijmegen, Toernooiveld 1, 6525

ED Nijmegen, The Netherlands

M. Miletto - H. J. Laanbroek

Department of Microbial Wetland Ecology,

Netherlands Institute of Ecology (NIOO-KNAW),

Centre for Limnology, Rijksstraatweg 6, 3631 AC

Nieuwersluis, The Netherlands continuously subjected to a full-factorial combination of tidal treatment [stagnant/tidal $(0.20 \mathrm{~m}$ amplitude)] and water type [(freshwater, oligohaline (salinity $=3$ )]. Soil, soil moisture and water nitrogen concentrations were monitored for a year, as well as vegetation response and nitrogen conversion rates in the soil. As expected, nitrogen mineralization rates were enhanced by the tidal treatment in comparison with the stagnant treatment. Denitrification rates however, were much less affected by tide and were even lower in the tidal treatments after 3 months in the agricultural grassland soils, implying that in general, soils were more oxic in the tidal treatments. Oligohaline treatments had virtually no effect on soil nitrogen conversion rates compared to freshwater treatments. Vegetation performance, however, was lower under saline conditions, especially in the semi-natural grassland. No further significant differences in response to the tidal and oligohaline treatments were found between the two soils although they differed strongly in soil characteristics. We conclude that if the rehabilitation measures in the former Haringvliet estuary are carried out as planned, drastic changes in soil nitrogen processes and vegetation composition will not occur.

Keywords Denitrification - Ecological restoration · Estuary · Grassland · Mesocosm experiment $\cdot$ Nitrogen 


\section{Introduction}

Estuarine systems are amongst the most valuable ecosystems in the world (Costanza et al. 1997). They provide a range of goods and services; for example, they play a major role in water purification and nutrient retention of large river systems (Tappin 2002; Neubauer et al. 2005; Gribsholt et al. 2005). In the last century, these systems have become globally threatened by river regulation (Ibanez et al. 1996; Coops et al. 1999), pollution (Bryan and Langston 1992; Hawkins et al. 2002), eutrophication (Flindt et al. 1999; Conley 1999; Kemp et al. 2005) and even complete closure of estuaries by dams for safety reasons or freshwater supply (Tenbrinke et al. 1994; Smit et al. 1997).

In the Netherlands the rivers Rhine and Meuse used to enter the North Sea in a combined estuary with a freshwater tidal marshland area in the upper reach (Biesbosch), unique in size for Europe (Zonneveld 1960), and an oligohaline part close to the sea (Haringvliet: Tönis et al. 2002) (Fig. 1). In 1970, the estuary was closed-off as part of the 'Deltaplan' invoked after the catastrophic 1953 flood (Nienhuis 1993). As a consequence, the Haringvliet became a large freshwater lagoon with a river discharge function for Rhine and Meuse. The original salinity gradient disappeared as the sluices in the Haringvliet Dam (North Sea side) are only opened during low tide to discharge river water (Withagen, 2000). The tidal amplitude decreased from $2 \mathrm{~m}$ before closure to only $20 \mathrm{~cm}$ maximum, as there is still a hydraulic connection with the North Sea through the Spui (Fig. 1). These changes in the physical and chemical environment had a very large effect; the surface of tidal flats decreased dramatically and sedimentation-erosion equilibriums were disturbed, resulting in very steep banks with narrow gradients (Tönis et al. 2002). Plant species specifically adapted to oligohaline water, salinity fluctuations and frequent submergence (i.e., Cochlearia officinalis L., Althaea officinalis L.), were replaced by plants, characteristic for hypertrophic conditions, i.e., Urtica dioica L., Epilobium hirsutum L. (Withagen 2000).

At present, there is a wide recognition with the general public, policymakers and ecologists, that the former Haringvliet-Biesbosch estuary had very high ecological values compared with the current situation (Ridgley and Rijsberman 1994). A management plan to regain some of the original values by restoring part of the seainfluence, has been developed and thoroughly scrutinized for negative side effects on safeguarding the hinterland and agricultural practices in the area (Driesprong et al. 1998). This plan includes measures to open up the sluices for two-way tidal currents; initially the sluices in the Haringvliet will be set only 'ajar' by 2008 (Kalsbeek 2004). Elaborate 'Environmental Impact Assessment Reports' were compiled in which effects of restoration on sedimentation-erosion equilibriums, water quality, fauna and vegetation were investigated by literature studies (e.g., Driesprong et al. 1998). The effects of reintroducing tide and a salinity gradient on nutrient cycling in the (new)

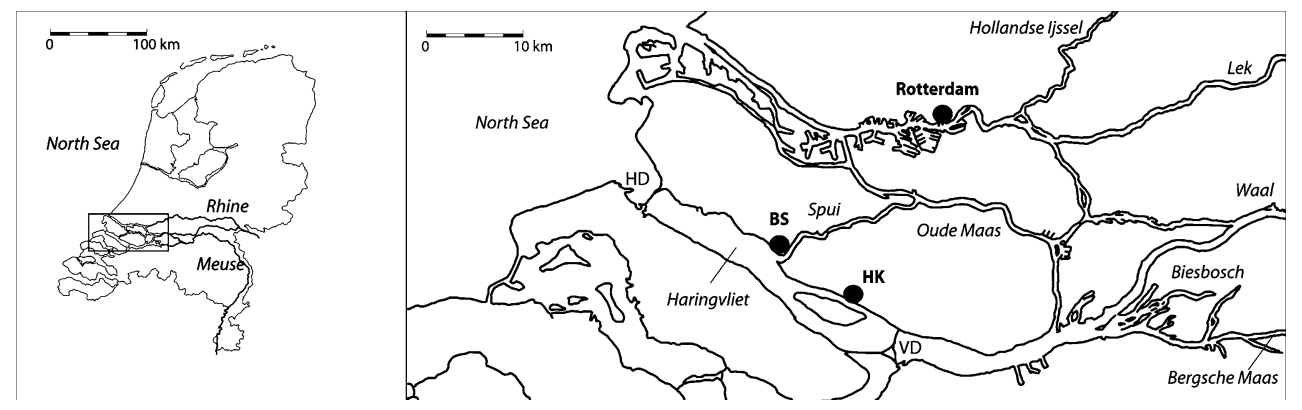

Fig. 1 Location of the Haringvliet estuary within the Netherlands and local tributaries of the rivers Rhine and Meuse. A limited hydraulic connection between the Haringvliet and the North Sea was maintained after closure through the Spui. 'BS'-Beninger Slikken is the semi-natural grassland sampling site and the agricultural grassland was sampled at 'HK'-Hitsertse Kade. The two dams closing off the Haringvliet estuary are indicated with HD-Haringvliet Dam, 1970 and VD-Volkerak Dam, 1969 
intertidal zones were given less attention, and to our knowledge, this has not been studied thoroughly before in estuarine systems in a restoration context.

In this study, we investigated the effects of tide and salinity on nitrogen dynamics in grasslands in the former estuary in order to be able to predict the future effects of restoration efforts. As many of the original marshlands have been cultivated and are currently in agricultural use, we compared semi-natural grasslands (which have changed from an oligohaline estuarine to a freshwater riverine environment) with agricultural grasslands (which have been fertilized and drained for at least 100 years). Both grassland types are envisaged to be rehabilitated by allowing more tidal influence and increased salinity. We studied the response of these two systems to renewed tidal and oligohaline conditions in an experimental approach with partly controlled environmental conditions. Soil-vegetation units (monoliths) from two locations in the Haringvliet area (Fig. 1) were transferred to outdoor mesocosms with controlled conditions with respect to tidal inundation and water salinity.

We expected biogeochemical nitrogen conversion rates to be higher in soils subjected to a tidal water regime due to a continuous fluctuation in oxygen supply, promoting both anaerobic (denitrification and dissimilatory nitrate reduction to ammonium) and aerobic processes (aerobic mineralization and nitrification) (e.g., Verhoeven et al. 1998; Flindt et al. 1999; Eriksson et al. 2003). In addition, we hypothesized that at least at the start of the experiment conversion rates would be lower in soils treated with oligohaline water compared to freshwater, as the microbial communities present are assumed to be specifically adapted to freshwater conditions and therefore would perform less under oligohaline conditions (Coci et al. 2005). This effect was expected to be less strong in the soil from seminatural grassland, in which the legacy of seainfluence might still be present in the composition of microbial communities after 35 years compared to the agricultural grasslands, where rain and drainage will have flushed out the soils for a period of at least 100 years. For similar reasons, we expected the semi-natural grassland vegeta- tion to adapt better to oligohaline conditions relative to vegetation from the agricultural grassland.

\section{Methods}

An outdoor mesocosm experiment in which soil monoliths from the Haringvliet area were subjected to salinity and tidal treatments for over 1 year was designed to test the hypotheses. The experiment was set up at the experimental facilities of Radboud University Nijmegen, the Netherlands.

\section{Study sites: soil monolith origin}

Soil monoliths with dimensions $60 \times 40 \mathrm{~cm}$ and $20 \mathrm{~cm}$ deep were taken from two areas in the former Haringvliet estuary (Fig. 1). The Beninger Slikken area $\left(51^{\circ} 47^{\prime} \mathrm{N}, 4^{\circ} 13^{\prime} \mathrm{E}\right)$ used to consist of tidal flats with oligohaline marshland and helophyte vegetation before 1970 . Nowadays, it is a protected freshwater marshland and the original vegetation is partly replaced by a semi-natural grassland characteristic for more freshwater conditions. The Hitsertse Kade area $\left(51^{\circ} 44^{\prime} \mathrm{N}\right.$, $\left.4^{\circ} 21^{\prime} \mathrm{E}\right)$ is an embanked narrow polder, fringing the Eendragstpolder, which was diked already in 1653 (Allewijn 1989). It has been in agricultural use (as a pasture) for at least the last century. Nonetheless, this small polder might be flooded at present at high water levels in the Haringvliet during winter. The soils from both locations were significantly different in physical characteristics with higher organic matter and soil moisture content in the semi-natural grassland. The more recent history of marine influence on the seminatural grassland compared to the agricultural grassland is clearly visible in soil moisture sulphate and sodium concentrations (Table 1). As the Hitsertse Kade is in use as a pasture, vegetation comprised primarily forage grasses; Agrostis stolonifera L. and Poa trivialis L. were found in all monoliths whereas Lolium perenne L. was co-dominant in some of the vegetation units: mean species number was only $3 \pm 1$ per soil monolith. Vegetation from the semi-natural grassland was more diverse (mean species 
Table 1 Initial inorganic soil nitrogen concentrations and soil physical characteristics in semi-natural grassland (SemN) and agricultural (Agr) soil, collected in May and June 2004 respectively

\begin{tabular}{|c|c|c|c|c|c|c|c|c|c|}
\hline \multirow[t]{2}{*}{ Soil } & \multicolumn{3}{|c|}{ Inorganic nitrogen $\left(\mathrm{mg} \mathrm{N} \mathrm{kg}^{-1}\right)$} & \multicolumn{4}{|c|}{ Physical soil conditions } & \multicolumn{2}{|c|}{ Marine indicators $\left(\mathrm{mg} \mathrm{kg}^{-1}\right)$} \\
\hline & $\mathrm{N}-\mathrm{NO}_{3}^{-}$ & $\mathrm{N}-\mathrm{NH}_{4}^{+}$ & Combined & $\operatorname{SOM}(\%)^{\mathrm{a}}$ & $\mathrm{W}^{\mathrm{b}}$ & Bulk $^{\mathrm{c}}$ & $\mathrm{pH}$ & $\mathrm{SO}_{4}^{2-}$ & $\mathrm{Na}^{+}$ \\
\hline SemN & $2.4 \pm 0.5$ & $3.8 \pm 0.6$ & $6.1 \pm 0.6$ & $14.7 \pm 0.6$ & $0.70 \pm 0.03$ & $1.25 \pm 0.04$ & $7.65 \pm 0.03$ & $1574 \pm 611$ & $101 \pm 10$ \\
\hline Agr & $13.1 \pm 1.5$ & $0.3 \pm 0.3$ & $13.4 \pm 1.5$ & $10.4 \pm 0.3$ & $0.26 \pm 0.01$ & $1.27 \pm 0.04$ & $7.63 \pm 0.01$ & $28 \pm 2$ & $8 \pm 2$ \\
\hline$P$-values & $0.000^{* * *}$ & $0.000 * * *$ & $0.000 * * *$ & $0.000 * * *$ & $0.000 * * *$ & 0.597 n.s. & 0.560 n.s. & $0.023^{*}$ & $0.000 * * *$ \\
\hline
\end{tabular}

In addition extractable $\mathrm{SO}_{4}^{2-}$ and $\mathrm{Na}+$ concentrations as indicators of a history of sea-influence are given. $P$-values result from an independent samples $T$-test, $* P<0.05$ and $* * * P<0.001$ between grassland types. Mean values \pm standard errors of the mean. $n=16$

${ }^{a}$ Soil organic matter content (\%)

${ }^{\mathrm{b}}$ Soil moisture content ( $\mathrm{g}$ water $\mathrm{g}$ dw soil ${ }^{-1}$ )

${ }^{\mathrm{c}}$ Bulk density $\left(\mathrm{g} \mathrm{cm}^{-3}\right)$

number was $15 \pm 2$ ), with many dicotyledonous species. A. stolonifera, Mentha aquatica L., Myosotis scorpioides L., P. trivialis, and Potentilla anserina L. were species with high abundance. Pulicaria dystenterica (L.) Bernh., Glaux maritima L. and Althaea officinalis, diagnostic species for vegetation types of (former) oligohaline conditions (Weeda et al. 1994), were still present in several soil monoliths.

\section{Experimental set-up}

The experiment was started in June 2004 and lasted until July 2005. The experimental design was full factorial with two factors: 'salinity', consisting of a fresh and oligohaline water type and 'tide', with a stagnant water level $10 \mathrm{~cm}$ below soil surface and a tidal version with levels fluctuating between $10 \mathrm{~cm}$ below and $10 \mathrm{~cm}$ above soil surface twice a day (Fig. 2). These levels were based either on the present situation for former tidal flats in the Haringvliet estuary (stagnant) and levels in the tidal regime mimic possible post-restoration levels, when these areas are once more subjected to a tidal regime. In each experimental unit one soil monolith from the semi-natural grassland site and one of the agricultural grassland site was placed. Per treatment combination (stagnant-fresh, stagnant-oligohaline, tidal-fresh and tidal-oligohaline) four replicates were used in the experiment.

Sixteen water basins with a volume of 2,500 1 were used, which were partly dug into the ground to mitigate strong water temperature fluctuations by solar heating. Artificial water types were made by adding a sea salt mixture (Meersalz Professional, Wiegandt $\mathrm{GmbH}$, Krefeld, Germany) to tap water, resulting in freshwater with a salinity of 0.1 and oligohaline water of salinity 3.0 , as determined by a salinity electrode (Multi 340i, WTW, Weilheim, Germany) (Table 2). A tidal movement was implemented in half of these basins by pumping app. $900 \mathrm{l}$ of water (from total of 2,100 1) to temporary storage basins over a period of $6 \mathrm{~h}$ (ebb) and a reverse of this process by passive outflow in the $6 \mathrm{~h}$ thereafter (flood) (Fig. 2). Occasionally, water had to be added to or removed from the basins during drought and rain periods, respectively, to maintain similar hydrological conditions. If salinity decreased below 3.0 in the oligohaline treatments, sea salt was added to restore the original value. On two occasions, during the winter of 2004/2005, the tidal movement had to be stopped for several days to prevent frost damage to the system. During this short pause, water levels were close to low tide.

\section{Sampling}

Soil, water and vegetation samples were taken throughout the experiment. Soil sampling was restricted to four main sampling campaigns: (1) during collections of the monoliths (May and June 2004), (2) 3 weeks after the start of the experiment (July 2004), (3) at the end of the growing season (October 2004) and 4. at the end of the experiment (July 2005). During the last 


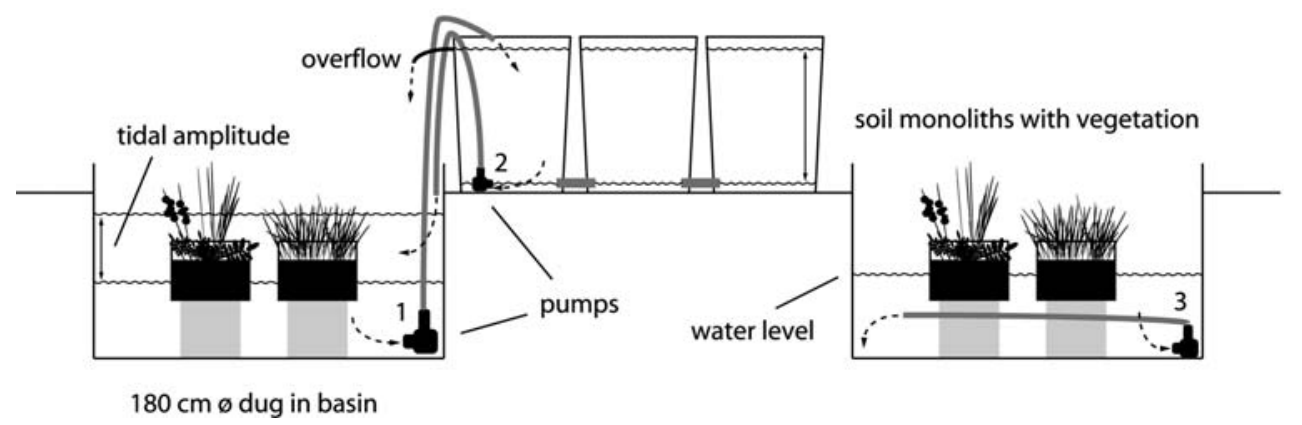

Fig. 2 Practical layout of the mesocosm experiment, with a tidal (a) and non-tidal (b) treatment. Per basins soil monoliths from both the semi-natural and agricultural grassland were present. Pump 1 in the tidal treatment is active during ebb; pump 2 initiates the (passive) flood. Pump 3 in the non-tidal treatment was working continuously to maintain a water current in these treatments as well. Dotted lines indicate direction of water movement

Table 2 Composition of fresh and oligohaline water types at the start of the experiment (June 2004) with respect to several relevant cat- and anions

\begin{tabular}{llllcrrl}
\hline Compound $\left(\mathrm{mg} \mathrm{l}^{-1}\right)$ & $\mathrm{NO}_{3}^{-}$ & $\mathrm{PO}_{4}^{3-}$ & $\mathrm{Cl}^{-}$ & $\mathrm{Na}^{+}$ & $\mathrm{K}^{+}$ & $\mathrm{SO}_{4}^{2-\mathrm{a}}$ & Salinity $(\%)^{\mathrm{b}}$ \\
\hline Freshwater type & $4.2 \pm 0.3$ & $0.03 \pm 0.01$ & $97 \pm 2$ & $61 \pm 1$ & $4.8 \pm 0.1$ & $59 \pm 1$ & 0.1 \\
Oligohaline type & $4.4 \pm 0.2$ & $0.04 \pm 0.01$ & $1314 \pm 28$ & $827 \pm 13$ & $33.5 \pm 0.7$ & $260 \pm 3$ & 3.0 \\
\hline
\end{tabular}

Concentrations were determined using a Inductively Coupled Plasma Optical Emission Spectrometer (ICP-OES, Spectro, Kleve, Germany). Mean values \pm standard errors of the mean, $n=8$

${ }^{a}$ Based on total sulphur measurements by ICP-OES

${ }^{\mathrm{b}}$ Measured with salinity electrode (Multi 340i, WTW, Weilheim, Germany)

two sampling campaigns plant biomass samples were collected as well. Surface water was sampled weekly during the first 2 months, then monthly and towards the end of the experiment bi-monthly.

Soil samples were taken with a foil corer $(\varnothing$ $4 \mathrm{~cm}$, length $10 \mathrm{~cm}$ ) (Eijkelkamp Agrisearch Equipment, Giesbeek, The Netherlands) to prevent disturbance of the soil cores. Soil cores for incubation purposes were collected with PVC tubes $(\varnothing 3 \mathrm{~cm}$, length $10 \mathrm{~cm}$ ). The holes in the monoliths, created by sampling, were filled by PVC tubes to keep the structure intact and prevent excess oxygen and water (with nutrients) from entering the soil. All soil samples were immediately put on ice and after transport to the laboratory stored at $4^{\circ} \mathrm{C}$. Samples were processed as quickly as possible, but not later than 1 week after collection.

Surface water was collected with $100 \mathrm{ml}$ polyethylene flasks in the well-mixed basins and stored at $-20^{\circ} \mathrm{C}$ until further analysis. Above- ground biomass was sampled by cutting a surface of $0.04 \mathrm{~m}^{2}$ at $1 \mathrm{~cm}$ above soil surface. The samples were stored at $4^{\circ} \mathrm{C}$ until analysis within 2 weeks.

\section{Chemical analyses}

Soil extractable concentrations of ammonium and nitrate were determined using a $0.4 \mathrm{M} \mathrm{KCl}$ extraction (Houba et al. 1989). $10 \mathrm{~g}$ of fresh material was weighed, $100 \mathrm{ml}$ of extraction solution was added and the sample was shaken for one hour at $100 \mathrm{rpm}$. The $\mathrm{pH}$ in the soil suspension was determined using a standard $\mathrm{pH}$ meter (WTW Measurement Systems, Ft. Myers, FL). After centrifuging (4 min 4,000 rpm) the supernatant was filtered over a glass microfibre filter (Whatman $\mathrm{GF} / \mathrm{C}$ ) and stored at $-20^{\circ} \mathrm{C}$ until concentrations $\mathrm{N}-\mathrm{NH}_{4}^{+}$and $\mathrm{N}-\mathrm{NO}_{3}^{-}\left(+\mathrm{N}-\mathrm{NO}_{2}^{-}\right)$ were determined colorimetrically on a continuous flow analyser (SA-40, Skalar Analytical, Breda, the Netherlands). 
Soil moisture content was determined gravimetrically after drying $20 \mathrm{~g}$ of fresh soil during $24 \mathrm{~h}$ at $105^{\circ} \mathrm{C}$. Bulk density was calculated with the (dry)weight of the soil cores and their known volumes. Soil organic matter content was determined by loss on ignition of dry ground soil at $550^{\circ} \mathrm{C}$ during $2.5 \mathrm{~h}$. Total soil nitrogen concentration was determined with a salicylic acid thiosulphate modification of the Kjeldahl digestion (Bremner and Mulvaney 1982). N concentration was determined colorimetrically on a continuous flow analyser (SA-40, Skalar Analytical, Breda, The Netherlands). The concentrations of $\mathrm{N}^{-\mathrm{NO}_{3}^{-}}\left(+\mathrm{N}-\mathrm{NO}_{2}^{-}\right)$and $\mathrm{N}-\mathrm{NH}_{4}^{+}$in the water samples were determined colorimetrically on an autoanalyser (Technicon AA II systems, Tarrytown, NY).

The aboveground biomass was sorted into living and senescent fractions, dried at $70^{\circ} \mathrm{C}$ for $48 \mathrm{~h}$, weighed, than ground and stored air-dry until further analysis. Plant tissue concentrations of $\mathrm{N}$ and $\mathrm{P}$ were determined on a continuous flow analyzer (SA-40, Skalar Analytical, Breda, The Netherlands) after a salicylic acid thiosulphate modification of the Kjeldahl digestion (Bremner and Mulvaney 1982).

Nitrogen conversion rate measurements

To estimate the actual denitrification rates in the field soil cores amended with acetylene were incubated in the laboratory at $18^{\circ} \mathrm{C}$ (Ryden et al. 1987). Acetylene inhibits the final step $\left(\mathrm{N}_{2} \mathrm{O}\right.$ to $\mathrm{N}_{2}$ conversion) in the chain of enzymatic reactions during denitrification (Yoshinari and Knowles 1976). The accumulation of $\mathrm{N}_{2} \mathrm{O}$ can be measured in the headspace as an estimation of the actual denitrification rate in the soil. We used a slightly adapted version of the method of Hefting et al. (2003), focusing on the accumulation of $\mathrm{N}_{2} \mathrm{O}$ after one hour of incubation compared to control measurements. Per soil monolith three soil cores were collected and wrapped in perforated aluminum foil. They were stored in 1.21 glass jars under ambient atmospheric conditions for $16 \mathrm{~h}$ at $4^{\circ} \mathrm{C}$ to slow down microbial processes as direct analysis was not possible due to logistic constraints. At the start of incubation, jars were flushed with $\mathrm{N}_{2}$ (at $18^{\circ} \mathrm{C}$ ) and sealed air-tight, amended with $100 \mathrm{ml}$ acetone-free acetylene (app. 10\% v/v) and incubated at average soil temperature $\left(18^{\circ} \mathrm{C}\right)$. Gas samples were taken through air-lock septa and analyzed by a gas chromatograph (Model 3300; Varian, Palo Alto, CA) equipped with an electron capture detector $\left(\right.$ ECD $\left.{ }^{63} \mathrm{Ni}\right)$ and Porapak Q columns (2-m-long packed columns; Alltech Associates, Deerfield, IL).

Potential denitrification rates (Denitrification Enzyme Activity-DEA) were determined at the end of the experiment (July 2005) to determine the size of the active denitrifying microbial community. Rates were measured in anoxic slurries with excess substrates added, composed of $10 \mathrm{~g}$ fresh wt soil and $10 \mathrm{ml}$ of incubation medium. Nitrogen was added to the medium as $\mathrm{KNO}_{3}$ to a final concentration of $10 \mu \mathrm{g} \mathrm{N}-\mathrm{NO}_{3}$ per $\mathrm{g}$ fresh wt soil, while easily degradable carbon sources were added to a final concentration of $2 \mathrm{mg} \mathrm{C}$-acetate and $2 \mathrm{mg}$ C-glucose per $\mathrm{g}$ fresh wt soil. Glass infusion flasks $(75 \mathrm{ml})$ containing $10 \mathrm{~g}$ of homogenized soil per soil monolith were evacuated through air tight septa. Per flask, $7 \mathrm{ml}$ acetylene was added plus $10 \mathrm{ml}$ of incubation medium and finally $\mathrm{N}_{2}$ until ambient air pressure was restored. Samples were vortexed and incubated at $18^{\circ} \mathrm{C}$. Gas samples were collected 4 and $8 \mathrm{~h}$ after incubation started. The increase in $\mathrm{N}_{2} \mathrm{O}$ concentration between the two sample moments was used to calculate DEA. This time window was chosen as the increase was still linear and had not been influenced by exponential bacterial growth (Hefting 2003). Gas sample analyses and calculations were done similarly as for the actual denitrification measurements.

Net mineralization rates were calculated by comparing the increase in $0.4 \mathrm{M} \mathrm{KCl}$ extractable inorganic nitrogen after a 14-day incubation at $18^{\circ} \mathrm{C}$ in the laboratory. Although this is a shorter period compared to those used in other studies (e.g., Verhoeven et al. 1990; Cookson et al. 2002), the duration is appropiate for obtaining a relative measure of mineralization representative for the differences caused by the treatments in our experiment. Soil cores were incubated aerobically in PVC tubes, closed off with a PVC lid at the lower end and sealed with perforated paraffin film at the top to prevent drying out but facilitating 
gas exchange. After incubation, soils were homogenized and extracted. Calculated mineralization rates were corrected for $\mathrm{N}$ losses due to denitrification derived from the actual denitrification rate measurements.

\section{Data analysis and statistics}

In all cases, statistical analyses of treatment effects were performed for soils from different origin separately. We chose this statistical approach as initial values of specific soil parameters were rather different (Table 1), which resulted in extremely heteroscedastic variables. Plant nutrient parameters met all conditions for performing ANOVA. Variances of soil nutrient parameters were in many cases heterogeneous as zero-values occurred, the most suitable solution to deal with this problem was determined for all tests individually; either transforming original data or performing non-parametric tests. A stepwise regression analysis was performed with the actual denitrification rate measurements of soil cores and the potential DEA measurements and several soil parameters (moisture content, soil $\mathrm{pH}$, organic matter content, total nitrogen and soil nitrate content) as explanatory factors. The data were grouped by soil origin for this analysis, regardless of the tidal or salinity treatments of the soil monoliths. The statistical software package SPSS 12.0.1 (SPSS Inc., Chicago, Ill.) was used for all statistical analyses.

\section{Results}

\section{Soil nitrogen parameters}

Inorganic nitrogen in the soil was initially higher in the agricultural grassland soils compared to the semi-natural grassland soils (Table 1). In general, this difference between soils persisted during the experiment (Rep Meas ANOVA, $F=25.459$, $P=0.000)$ (Fig. 3a-b). Treatment effects on inorganic soil nitrogen concentrations were restricted to measurements at the end of the experiment (July 2005). A significant effect was only observed for semi-natural grassland soils ( $\mathrm{Ln}$ transformed data, 2-way ANOVA, $F=5.804, P=0.033$ ), in which inorganic nitrogen was higher in tidal than in stagnant treatments, whereas this effect was not significant for the agricultural grassland soil (2-way ANOVA, $F=4.154, P=0.064$ ). The two soil types differed in the importance of the two inorganic nitrogen species ammonium and nitrate. Ammonium was the dominant species in the semi-natural grassland soil from the start and this did not change during the experiment, regardless of the treatments (Fig. 3a). In the agricultural grassland soil, nitrate was high while ammonium was almost absent before the experiment. In July 2004, 3 weeks after the onset of the experiment, nitrate had decreased and ammonium had increased rapidly in the tidal treatments. From October 2004 onwards ammonium was the dominant $\mathrm{N}$ species in the agricultural soils too.

Total nitrogen concentrations were higher in the semi-natural grassland soils compared to agricultural soils in both July 2004 and July 2005 (T-Test, $T=6.473, \quad P=0.000$ and $t=3.053$, $P=0.006$ respectively, Table 3 ). No treatment effects within one sampling time were found except in the tidal-fresh treatments, where total $\mathrm{N}$ was significantly lower in July 2005 compared to a year earlier for monoliths from the semi-natural grassland soils.

Nitrate concentrations in the surface water dropped within 1 month after the start of the experiment from values of $1.5-2.5 \mathrm{mg} \mathrm{N}^{-1}$ to approximately $0.5 \mathrm{mg} \mathrm{N}^{-1}$ (Fig. 4a) in all treatments. In July 2004, an effect of tide was present with higher nitrate concentrations in tidal compared to stagnant treatments (squared root transformed data, ANOVA, $F=9.550, P=0.009$ ). In October 2004 however, the effect was no longer present (squared root transformed data, ANOVA, $F=2.614, P=0.132)$. Ammonium was low in the surface water at the start of the experiment; only from mid July onwards ammonium was found in all basins (Fig. 4b). During the growing season (approximately April until September), ammonium in the surface water generally increased until the end of August, but decreased from September onwards to below detection limits $\left(0.1 \mathrm{mg} \mathrm{N}^{-1}\right)$. No treatment effects on ammonium concentration in the surface water were present at any of the sampling times. 


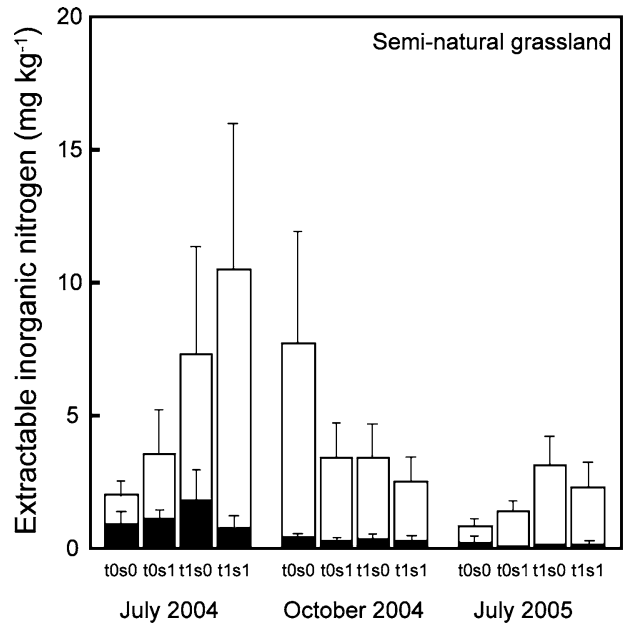

Fig. 3 Concentrations of $0.4 \mathrm{M} \mathrm{KCl}$ extractable inorganic nitrogen, as summation of $\mathrm{N}-\mathrm{NO}_{3}^{-}$(black bars) and $\mathrm{N}-\mathrm{NH}_{4}^{+}$ (white bars) during the experiment per treatment. Soil samples were collected in July, October 2004 and July 2005 Treatment codes indicate; t0s0: stagnant-fresh, t0s 1 :

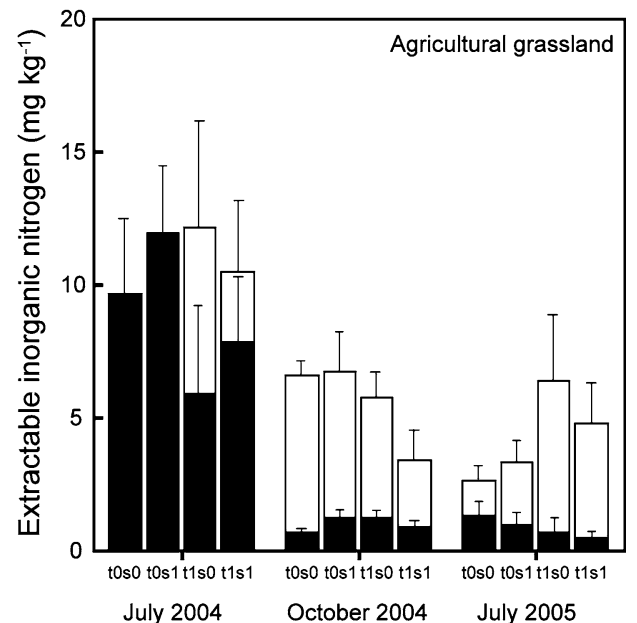

stagnant-oligohaline, t1s0: tidal-fresh and t1s1: tidal-oligohaline. Values are presented separately for the seminatural (left) and agricultural grassland soils (right). Error bars indicate standard error of the mean, $n=4$

Table 3 Changes in total (organic and inorganic) nitrogen in the soil $\left(\mathrm{mg} \mathrm{g}^{-1}\right)$ during the experiment as affected by tidal and salinity treatments for the semi-natural and agricultural grassland separately

$\begin{array}{llll}\text { Tide0-Salt0 } & \text { Tide0-Salt1 } & \text { Tide1-Salt0 } & \text { Tide1-Salt1 }\end{array}$

Semi-natural grassland

Total soil $N$ concentration $\left(\mathrm{mg} \mathrm{g}^{-1}\right)$

July 2004

July 2005

$3.84 \pm 0.25$

$2.60 \pm 0.58$

0.123 n.s.

$P$-value $T$-test (2-tailed)

Agricultural grassland

Total soil $N$ concentration $\left(\mathrm{mg} \mathrm{g}^{-1}\right)$

July 2004

July 2005

$P$-value $T$-test
$3.82 \pm 0.26$
$4.61 \pm 0.74$
0.483 n.s.

$3.49 \pm 0.19$

$2.30 \pm 0.43$

0.139 n.s.

$$
\begin{aligned}
& 5.35 \pm 0.63 \\
& 3.12 \pm 0.80 \\
& 0.014^{*}
\end{aligned}
$$

$4.37 \pm 0.72$

$3.77 \pm 0.64$

0.328 n.s.

$$
\begin{aligned}
& 3.46 \pm 0.20 \\
& 2.25 \pm 0.27 \\
& 0.081 \text { n.s. }
\end{aligned}
$$

$3.12 \pm 0.15$

$2.10 \pm 0.31$

0.068 n.s.

The significance of change over the year within a treatment was tested using an independent samples $T$-test. ANOVA analyses of soil nitrogen differences within a sampling campaign between treatments did not yield any significant differences. Values are \pm standard errors of the mean, significant effects are indicated with $* P<0.05, n=4$

\section{Actual nitrogen conversion rates}

Three weeks after the start of the experiment (July 2004), no treatment effects on either denitrification or mineralization rate were detected for both soil types (not shown). The measurements during October 2004 revealed that the tidal treatment had reduced actual denitrification rates in the agricultural soil compared to stagnant treatments, whereas still no effects were present for the seminatural grassland soil (Fig. 5a, Table 4). No significant models were obtained by stepwise regression analyses of denitrification with soil parameters as explanatory variables for both soil types and both sampling moments (July 2004 and October 2004).

Treatment effects of tide were present for mineralization rates, with higher rates in tidal treatments compared to stagnant treatments in both semi-natural and agricultural grassland soils (Fig. 5b, Table 4). No direct effects of the salinity treatments were present; only an interaction effect was found for mineralization rates in the semi-natural soils, related to negative values (i.e., nitrogen immobilization) for the stagnant-fresh 


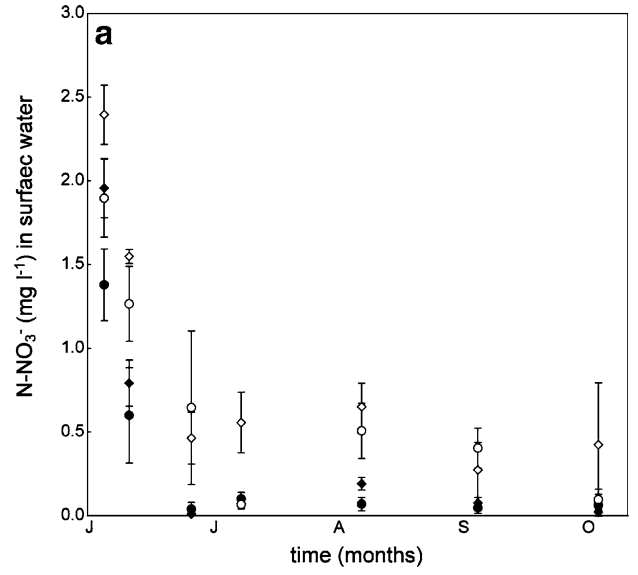

Fig. 4 Concentrations of $\mathrm{N}-\mathrm{NO}_{3}^{-}(\mathbf{a})$ and $\mathrm{N}-\mathrm{NH}_{4}^{+}(\mathbf{b})$ in the water compartments of the mesocosm during the experiment from June 2004 to October 2004. Tidal treatments are indicated by open (tidal movement present) and closed

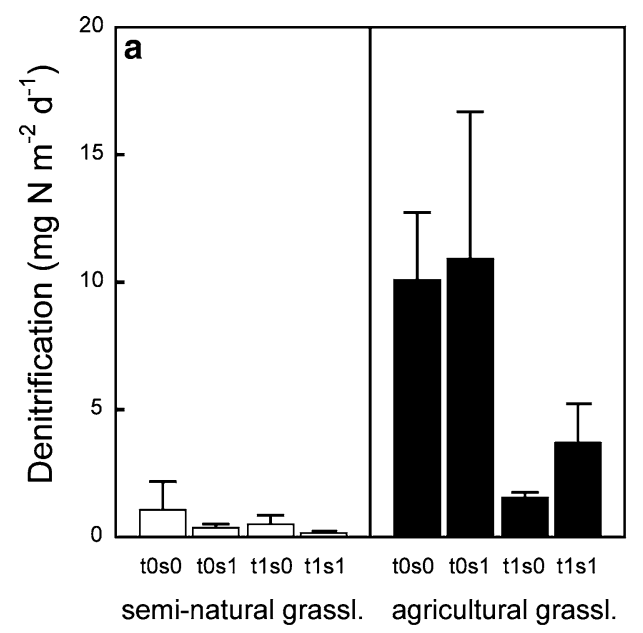

Fig. 5 Soil nitrogen conversion rates (measurements: October 2004); denitrification (a) and mineralization (b) rates per treatment. Treatment codes indicate; t0s0: stagnant-fresh, t0s1: stagnant-oligohaline, t1s0: tidal-fresh and t1s1: tidal-oligohaline. Values are presented separately

treatment combination. Furthermore, overall nitrogen conversion rates was higher in the agricultural grassland soils compared to the semi-natural grassland soils, especially denitrification rates were almost one magnitude higher.

\section{Potential denitrification rates}

Potential denitrification rates were on average lower in the semi-natural grassland soils, $609 \pm 168$ compared to $974 \pm 542 \mathrm{mg} \mathrm{N} \mathrm{m}^{-2} \mathrm{~d}^{-1}$

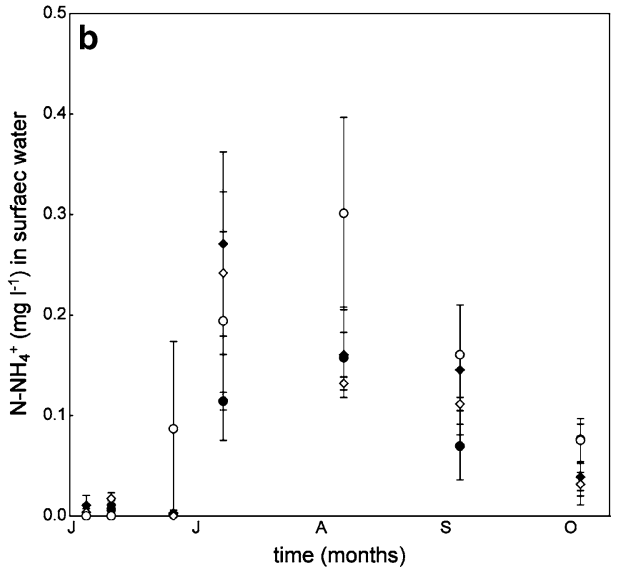

markers (stagnant), salinity conditions are indicated by diamonds (freshwater) and circles (oligohaline). Error bars indicate standard error of the mean, $n=4$

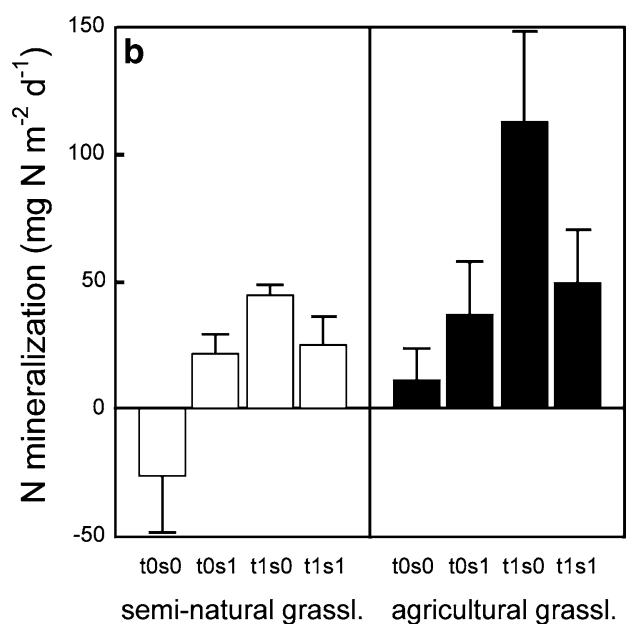

for the semi-natural (white bars) and agricultural grasslands (black bars) Refer to Table 4 for statistical testing of possible treatment effects. Error bars indicate standard error of the mean, $n=4$

for the agricultural grassland ( $T$-test $P=0.000$, Fig 6). A treatment effect was present for salinity, with DEA values lower in oligohaline treatments for the agricultural soil only (2-way ANOVA, $F=5.300, P=0.04)$.

The soil parameters selected as explanatory variabels in a stepwise regression analysis with DEA as dependent variable did not yield a significant model for soil monoliths from the semi-natural grassland soils. However, a significant model $(P=0.037)$ was obtained for the 
Table 4 Results of two-way ANOVA's concerning soil nitrogen conversion rates and quantitative biomass parameters at the end of the first growing season (October 2004)

\begin{tabular}{|c|c|c|c|c|c|c|}
\hline & \multicolumn{2}{|l|}{ Tide } & \multicolumn{2}{|c|}{ Salinity } & \multicolumn{2}{|c|}{ Tide $\times$ Salinity } \\
\hline & $F$ & $P$-value & $F$ & $P$-value & $F$ & $P$-value \\
\hline \multicolumn{7}{|c|}{ Semi-natural grassland } \\
\hline \multicolumn{7}{|c|}{ Soil nitrogen conversion rates } \\
\hline Ln denitrification & 0.286 & 0.602 & 0.661 & 0.432 & 0.000 & 0.983 \\
\hline Mineralization & 8.265 & $0.014 *$ & 1.211 & 0.293 & 6.648 & $0.024 *$ \\
\hline \multicolumn{7}{|c|}{ Quantitative biomass parameters } \\
\hline Aboveground biomass & 0.513 & 0.487 & 7.512 & $0.018 *$ & 1.983 & 0.184 \\
\hline $\mathrm{N}$ standing stock & 0.035 & 0.855 & 3.964 & 0.070 & 0.205 & 0.659 \\
\hline Ln N standing stock & 0.502 & 0.823 & 5.052 & $0.044 *$ & 0.077 & 0.787 \\
\hline $\mathrm{N}: \mathrm{P}$ mass ratio & 0.246 & 0.629 & 0.772 & 0.379 & 0.120 & 0.735 \\
\hline Nitrogen concentration & 0.048 & 0.830 & 0.334 & 0.547 & 1.106 & 0.314 \\
\hline \multicolumn{7}{|c|}{$\begin{array}{l}\text { Agricultural grassland } \\
\text { Soil nitrogen conversion rates }\end{array}$} \\
\hline Ln denitrification & 8.521 & $0.013 *$ & 0.185 & 0.675 & 0.684 & 0.424 \\
\hline Mineralization & 4.826 & $0.048 *$ & 0.533 & 0.479 & 2.933 & 0.112 \\
\hline \multicolumn{7}{|c|}{ Quantitative biomass parameters } \\
\hline Aboveground biomass & 1.252 & 0.285 & 3.807 & 0.075 & 1.192 & 0.296 \\
\hline $\mathrm{N}$ standing stock & 0.447 & 0.516 & 1.796 & 0.205 & 0.383 & 0.548 \\
\hline $\mathrm{N}: \mathrm{P}$ mass ratio & 0.947 & 0.343 & 2.727 & 0.125 & 0.628 & 0.443 \\
\hline Nitrogen concentration & 4.297 & 0.060 & 1.407 & 0.258 & 1.059 & 0.324 \\
\hline
\end{tabular}

Statistical testing was performed within soil type for effects of the experimental factors 'tide' (stagnant vs. tidal movement) and 'salinity' (fresh vs. oligohaline). Significant effects are indicated with $* P<0.05, n=4$ (See Fig. 5a-b and 7a-d)

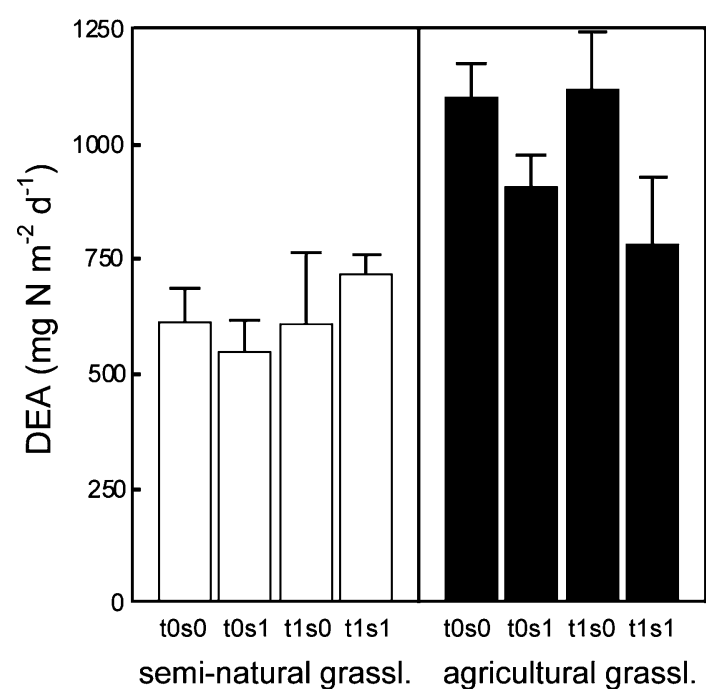

Fig. 6 Potential denitrification rates (DEA) per treatment (measurements: June 2005). Treatment codes indicate; t0s0: stagnant-fresh, t0s1: stagnant-oligohaline, $\mathrm{t} 1 \mathrm{~s} 0$ : tidal-fresh and t1s1: tidal-oligohaline. Values are presented separately for the semi-natural (white bars) and agricultural grasslands (black bars). Error bars indicate standard error of the mean, $n=4$

agricultural grassland soil, with soil nitrate concentration as the only significant independent variable for DEA in the regression model.
Vegetation parameters

At the end of the growing season (October 2004), standing biomass was not significantly different between semi-natural and agricultural grassland monoliths ( $T$-test, $t=1.715, P=0.097$ ) (Fig. 7a). In the semi-natural grasslands, biomass was significantly less in oligohaline treatments compared to freshwater treatments (Table 4). No effect of tide on biomass was detected. Standing biomass on the agricultural grassland monoliths soils was not affected by either tide or salinity treatments. Nitrogen standing stock - the amount of nitrogen in aboveground biomass per soil surface-was not significantly different between soil monoliths from semi-natural or agricultural origin at the end of the growing season ( $T$-test, $t=0.164$ $P=0.871$ ) (Fig. 7b). Ln transformed data did reveal a negative effect of oligohaline treatments on $\mathrm{N}$ standing stock on the semi-natural grassland monoliths related to biomass differences compared to fresh treatments, while this effect was absent for the agricultural grassland vegetation. No treatment effects of tide were found in both vegetation types. Nitrogen concentrations and 

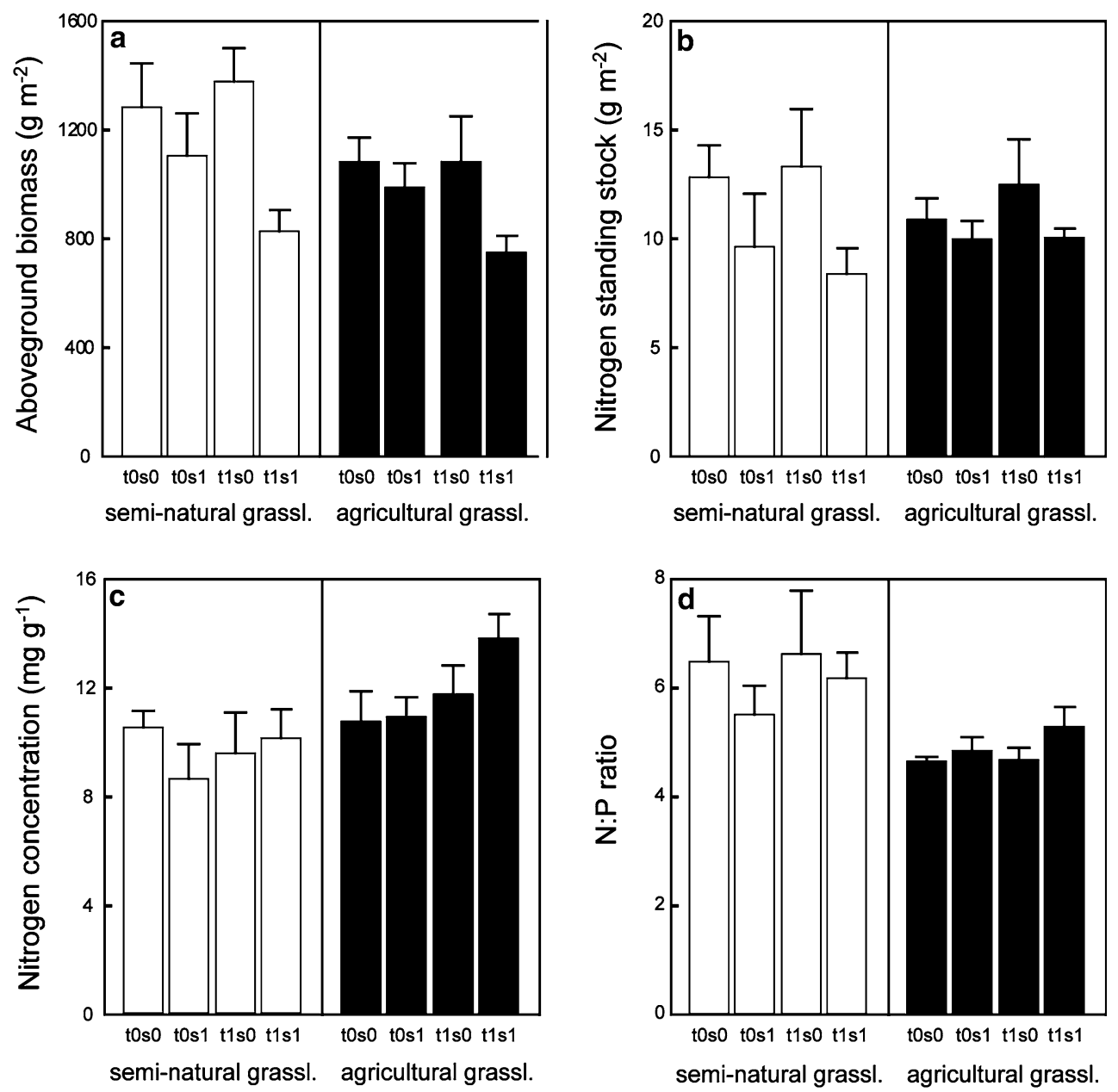

Fig. 7 Quantitative vegetation variables per treatment (October 2004). Values of peak standing biomass (a), nitrogen standing stock (b), nitrogen concentration in living biomass (c) and N:P mass ratio in living biomass (d). Treatment codes indicate; t0s0: stagnant-fresh, t0s1: stagnant-oligohaline, t1s0: tidal-fresh and t1s1: tidal-oli-

gohaline. Values are presented separately for the seminatural (white bars) and agricultural grasslands (black bars) Refer to Table 4 for statistical testing of possible treatment effects. Error bars indicate standard error of the mean, $n=4$

$\mathrm{N}: \mathrm{P}$ mass ratios in living tissue were different between vegetation from different origin (Figs. 7c-d), with highest $\mathrm{N}$ concentrations in the agricultural grassland vegetation ( $T$-test, $t=2.766$, $P=0.01)$ but lowest $\mathrm{N}: \mathrm{P}$ ratios ( $T$-test, $t=3.358$, $P=0.003)$. No treatment effects on tissue nutrients were found for both vegetation types.

\section{Discussion}

Two main important points can be derived from this study: firstly, tidal treatment enhanced

mineralization rates as expected whereas denitrification was either lower or not affected, which was not foreseen. Secondly, oligohaline treatments had virtually no effect on soil nitrogen conversion rates and soil nitrogen concentrations, whereas it did have a negative effect on productivity of the vegetation of the semi-natural grassland only.

Mesocosm application considerations

Mesocosm experiments are designed to mimic a selected part of existing ecosystems to study processes at a small scale more closely (e.g., 
Odum 1984; Carpenter 1996). In our case, the experiment was used to study nitrogen processes in two soil-vegetation types. The starting point was comparable to field conditions, but a divergence from the actual situation in the field occurred over time, concerning mostly the input and output of inorganic nitrogen, but also contents of organic matter and associated organic nitrogen (and phosphorus). Surface water nitrate concentrations decreased rapidly over time (Fig. 4a), most likely by denitrification or consumption by plants and algae. In the field situation, nitrate would be replenished continuously by either river water input (e.g., Jordan et al. 1983; Howarth et al. 1996; Verhoeven et al. 2006) or possibly also by nitrogen-enriched groundwater (Flindt et al. 1999; Tappin 2002). The overall depletion of nitrogen in the mesocosms was also visible in the decrease in organic nitrogen over 1 year (Table 3, T-test all measurements combined, $t=3.952, P=0.000)$ and the significantly lower nitrogen concentrations in plant tissue at the end of the experiment (not shown) compared to concentrations at the end of the first growing season (October 2004). Therefore we restricted ourselves predominantly to results from analysis in the first period of the mesoscosm experiment (until October 2004). Another experimental issue is the calculation of mineralization rates following incubation trials. We corrected for $\mathrm{N}$-losses by denitrification, which probably lead to less accurate data as errors in the original values are propagated in the resulting values. However, if the data do not represent an exact quantitative estimate, they can be used as an indication of the order of magnitude of the mineralization process.

Comparison of semi-natural and agricultural grassland soils

The total soil nitrogen concentrations found in this study, on average $4.3 \mathrm{mg} \mathrm{g}^{-1}$ for semi-natural grassland soils and $3.4 \mathrm{mg} \mathrm{g}^{-1}$ for agricultural grasslands soils, are comparable with values found for grassland soils in earlier studies; i.e., up to $3.75 \mathrm{mg} \mathrm{g}^{-1}$ for 50 -year-old L. perennegrasslands (Accoe et al. 2004) and $2.95 \mathrm{mg} \mathrm{g}^{-1}$ for a grazed floodplain grassland (Van Oorschot et al. 2000). Lowest total nitrogen concentrations were found in the soils from the agricultural grassland. Although one might expect those to be higher due to decades of fertilization and manure applications (Schott 2001; Edmeades 2003), the higher organic matter content in the semi-natural grassland soil apparently has resulted in higher organic (total) nitrogen concentrations (Morse et al. 2004; Antheunisse and Verhoeven 2006). Nevertheless, the effects of agricultural use are clearly visible in the concentration of inorganic nitrogen in the soil, which is highest in the agricultural grasslands soils throughout the experiment (Fig. 3). In addition, biogeochemical process rates involving nitrogen conversionsmineralization and denitrification-were also higher in these monoliths (Fig. 5). This is most likely caused by a difference in the quality and degradability of organic matter (Scott and Binkley 1997) although the $\mathrm{C} / \mathrm{N}$ ratio of organic matter was not different between the two soil types. Values up to $10 \mathrm{mg} \mathrm{N} \mathrm{m}^{-2} \mathrm{~d}^{-1}$ for denitrification found in the agricultural grassland soils were equal to the highest levels measured in a study of managed grassland soils in The Netherlands (De Klein and Van Logtestijn 1994) or in chronically nitrate-loaded grass-vegetated riparian buffer zones (Hefting and de Klein 1998). They were well within the range of 1 and $25 \mathrm{mg} \mathrm{N} \mathrm{m}^{-2} \mathrm{~d}^{-1}$ documented for Dutch floodplain grasslands (Verhoeven et al. 1998). Higher mineralization rates will lead to faster turnover of plant litter and soil organic matter and are therefore most likely also responsible for the difference in soil organic matter content between the semi-natural and agricultural grassland soils (Bridgham et al. 1998; Haag and Kaupenjohann 2001).

Ammonium concentrations were similar across both soil types, apart from higher ammonium concentrations in the semi-natural grassland soil during tidal conditions in the first month of the experiment. This difference was most likely caused by the initially higher soil moisture content of these soils, promoting dissimilatory nitrate reduction (Bonin et al. 1998), meanwhile suppressing nitrification due to oxygen shortage (Phillips 1999). During the experimental period, soil moisture levels in both soil types became more alike and similar to the original values of the semi-natural grassland soil (not shown), 
resulting in relatively high ammonium concentrations compared to nitrate. Nitrate concentrations remained higher in the agricultural grassland soil until the end of the experiment due to higher mineralization and nitrification rates (Van Oorschot 1994; Phillips 1999). Differences in inorganic soil nitrogen were reflected in standing biomass nitrogen concentrations, which were higher in the agricultural grassland vegetation.

Not only actual denitrification rates, but also potential denitrification (DEA) rates were highest in the agricultural grassland soil. This suggests that the active population of denitrifiers is larger in these soils, probably as a consequence of higher availability of nitrate or electron donors (carbon). Furthermore, from the stepwise regression analyses it can be deduced that, within this mesocosm experiment, there is an overall control of potential DEA by soil nitrate concentrations with respect to the agricultural grassland soils. This is in line with earlier studies (e.g., Reddy and Patrick Jr. 1984; Groffman and Tiedje 1989; Schipper et al. 1993). Additional analyses revealed that indeed in both soil types nitrate and/ or carbon addition increased DEA (not shown). However, actual denitrification rates as measured in intact cores were not controlled by any of these soil parameters. They are influences by treatment induced effects (i.e., tide) and varation in parameters operating on a smaller spatial scale, such as oxygen availability.

\section{Effects of tide}

We expected nitrogen conversion rates to be higher in soils subjected to a tidal water regime. Indeed, mineralization rates were higher in the tidal treatments across both grassland soil types, probably as a results of (temporarily) oxic conditions in these treatments (Flindt et al. 1999). Denitrification rates however, were not positively affected by tide, even lower denitrification rates were measured for tidally treated agricultural grassland soil monoliths in October 2004, compared to the stagnant treatments. If the actual denitrification rates would have been slowed down by depletion of the nitrate pool in October 2004, we would have expected to see higher denitrification rates during the July 2004 measurements in these monoliths, causing a faster depletion. However, no such treatment effects were present at the time (not shown). Therefore, we have to consider an alternative explanation; the tidal treatment did not enhance a coupling of nitrification/denitrification processes (Patrick Jr. and Reddy, 1976), but it led to a more oxic soil compartment, and was therefore less favourable for denitrification (Olde Venterink et al. 2003). This explanation is supported by the fact that nitrate concentrations, although depleting rapidly as well, remained somewhat higher in the tidal basins compared to the stagnant treatments in July 2004. On the other hand, the faster replacement of nitrate by ammonium in the soil in the tidally treated agricultural grassland monoliths compared to stagnant treatments does not support the alternative explanation directly. It can be seen as an argument in favour of the original hypothesis as it suggests an overall lower oxygen availability in the tidal treatments, with accumulation of ammonium as a consequence (e.g., Waring and Bremner 1964; Buresh and Patrick Jr. 1981; Bowden 1986). However, the apparent lower activity of ammonia-oxidizing bacteria in more oxygen-rich tidal treatments could be subscribed to the fact that they are poorer competitors for oxygen compared to the relatively large population of aerobic decomposers in these soils (Bodelier and Laanbroek 1997). Although neither detailed redox nor soil moisture oxygen saturation data are available, the aforementioned arguments support the alternative hypothesis stating that a relatively more oxic condition is on average present in the tidal treatments.

The N:P mass ratios in aboveground living tissue $(<<14)$ and rather low nitrogen concentrations (ca. $10 \mathrm{mg} \mathrm{g}^{-1}$ ) suggest limitation of plant growth by nitrogen availability (Koerselman and Meuleman 1996; Güsewell et al. 2003). Therefore we would expect effects of enhanced nitrogen mineralization rates on productivity, with higher plant biomass and $\mathrm{N}$ standing stock in tidal treatments. However, we did not find any effects of tidal treatment-combinations on vegetation parameters. This could be due to the fact that at the time of the start of the experiment, vegetation was already halfway the growing season. Nitrogen uptake occurs mainly in the first half of the 
growing season and this might obscure effects of N shortage (Greenwood et al. 1990). However, analysis of vegetation parameters on collected biomass samples from July 2005, 1 year after the start of the experiment did not reveal any significant effects either (not shown). This suggests that, although nitrogen is a probable candidate in limiting productivity, this element was not limiting plant growth in our experiment to the extent that we could measure it in biomass responses. Aboveground biomass values in our experiment were rather high, clearly above $600 \mathrm{~g} \mathrm{~m}^{-2}$, which is often regarded as upper limit for nutrient availability controlled growth (Wassen et al. 2005).

\section{Effects of salinity}

In contrast to our expectation, we did not find any effects of the oligohaline treatments on either soil nitrogen conversion rates or nitrogen content. We hypothesized that especially in the agricultural grassland soil, microbial communities would specifically be adapted to freshwater conditions and therefore would perform less well under imposed oligohaline treatments (Coci et al. 2005). This was less expected for the semi-natural grassland soils, although the oligohaline treatment did significantly increase the concentration of salt indicators in the soil pore water (Loeb, unpublished data). It is possible that the salinity used in the oligohaline treatments (salinity of 3) was too low to have an inhibiting effect on nitrogen conversion rates. Supporting evidence on these matters is scarce as experimentally imposed salinity changes are rare; Rysgaard et al. (1999) documented a large reduction in denitrification activity in estuarine sediments when salinity was raised from 0 to 10 . The experimental difference in salinity in their setup is unfortunately too large to be helpful in either supporting or refuting our assumptions.

Although no effects on actual nitrogen conversion rates were found, we were able to detect a salinity effect for potential denitrification measurements (DEA). Lower rates were present under oligohaline conditions for the agricultural grassland soil only. This supports our hypothesis, that the agricultural soil would have more difficulties to adapt to changing salinity, as no legacy of sea influence was present. We were not able to detect this by the actual denitrification measurements, as either nitrate or carbon was limiting nitrogen conversion processes strongly and thereby obscuring the salinity effect.

In addition, we also expected a negative effect of oligohaline conditions on vegetation performance (biomass and nutrient uptake). Significantly lower biomass was indeed found for the semi-natural grassland vegetation under oligohaline conditions (non-significant trend for the agricultural grassland vegetation $-P=0.075$ ). Nitrogen in plant standing stock was also lower on oligohaline treated soil monoliths from the semi-natural grassland. Although the main effect was as expected, we anticipated the largest (negative) salinity effects on the agricultural grassland. This vegetation was expected to be less adapted to oligohaline conditions, which was not confirmed by our data. Therefore it is likely that the imposed treatment with a salinity of 3 was still rather low and inflicted only minor stress on both the semi-natural and agricultural grassland vegetation.

\section{Consequences for estuarine rehabilitation}

The main conclusion of this experimental study, addressing the possible effects of renewed tide and salinity in the closed-off Haringvliet estuary, is that effects on actual soil nitrogen processes and shore grassland vegetation were rather limited within the time frame of the experiment. We only found effects by an imposed tidal regime. In addition, no large differences in response between the two studied soil types were found although they differed strongly in soil characteristics (Table 1). The implication of this finding is that the nitrogen dynamics of semi-natural grasslands in the former estuary still function in a way similar to the original, oligohaline situation with tides. Therefore, rehabilitation planning will not change the nitrogen dynamics of these systems. We are confident to say that if the rehabilitation measures in the former Haringvliet estuary are carried out as planned, drastic changes in soil nitrogen processes and consequently the availability of nitrogen for plant growth, but also 
vegetation composition, even in agricultural grasslands, will not occur. A more gradual change over the years is expected when dominant plant species in present situation will be replaced by species more characteristic for oligohaline tidal conditions, although this might take decades (Piesschaert et al. 2005).

Our findings may apply to ecological restoration of estuarine systems in general, as far as vegetated sites cut off from tidal action are concerned. We did not detect large changes for the Haringvliet estuary in our experiment, therefore we expect that in comparable estuarine rehabilitation projects, measures will not lead to an increase in nitrogen availability for the vegetation. Consequently, effects on plant productivity and vegetation (composition) will be relatively small. However, this only holds as long as restoration leads to a moderate increase in salinity only and if the present vegetation is able to survive the renewed tidal movement.

Acknowledgements This study was financially supported by the Netherlands Organisation for Scientific Research (NWO). It was part of the TRIAS programme within the project 'Biogeochemical constraints for sustainable development of floodplains in riverine regions' (project 835.80.010). We thank the terrain owners-Vereniging tot Behoud van Natuurmonumenten and Mr. Holster-for kindly giving permission to collect monoliths on their properties and all MSc-students and co-workers involved in collecting and analyzing the samples. Finally, we would like to thank two anonymous reviewers for very helpful comments on an earlier version of this paper.

\section{References}

Accoe F, Boeckx P, Busschaert J, Hofman G, Van Cleemput O (2004) Gross $\mathrm{N}$ transformation rates and net $\mathrm{N}$ mineralisation rates related to the $\mathrm{C}$ and $\mathrm{N}$ contents of soil organic matter fractions in grasslands soils of different age. Soil Biol Biochem 36:2075-2087

Allewijn R (1989) En wijd was de polder. Van As BV, Oud Beijerland, (In Dutch)

Antheunisse AM, Verhoeven JTA (2006) Restoration of natural hydrological and salinity gradients in tidal rivers; consequences for helophyte vegetation. Estuar. Coast Shelf Sci (In review)

Bodelier PLE, Laanbroek HJ (1997) Oxygen uptake kinetics of Pseudomonas chlororaphis grown in glucose- or glutamate-limited continuous cultures. Arch Microbiol 167:392-395
Bonin P, Omnes P, Chalamet A (1998) Simultaneous occurrence of denitrification and nitrate ammonification in sediments of the French Mediterranean Coast. Hydrobiologia 389:169-182

Bowden WB (1986) Nitrification, nitrate reduction, and nitrogen immobilization in a tidal freshwater marsh sediment. Ecology 67:88-99

Bremner JM, Mulvaney CS (1982) Salicylic acid-thiosulphate modification of Kjeldahl method to include nitrate and nitrite. In: Page AC, Miller RH, Keeney DR (eds) Agronomy 9: Methods of soil analyses; part 2, Chemical and microbiological properties. Soil science society of America, Madison, pp 621-622

Bridgham SD, Updegraff K, Pastor J (1998) Carbon, nitrogen, and phosphorus mineralization in northern wetlands. Ecology 79:1545-1561

Bryan GW, Langston WJ (1992) Bioavailability, accumulation and effects of heavy-metals in sediments with special reference to United-Kingdom estuaries-a review. Environ Pollut 76:89-131

Buresh RJ, Patrick Jr. WH (1981) Nitrate reduction to ammonium and organic nitrogen in an estuarine sediment. Soil Biol Biochem 13:279-283

Carpenter SR (1996) Microcosm experiments have limited relevance for community and ecosystem ecology. Ecology 77:677-680

Coci M, Riechmann D, Bodelier PLE, Stefani S, Zwart G, Laanbroek HJ (2005) Effect of salinity on temporal and spatial dynamics of ammonia-oxidising bacteria from intertidal freshwater sediment. FEMS Microbiol Ecol 53:359-368

Conley DJ (1999) Biogeochemical nutrient cycles and nutrient management strategies. Hydrobiologia 410:87-96

Cookson WR, Cornforth IS, Rowarth JS (2002) Winter soil temperature (2-15 degrees C) effects on nitrogen transformations in clover green manure amended or unamended soils; a laboratory and field study. Soil Biol Biochem 34:1401-1405

Coops H, Geilen N, Van der Velde G (1999) Helophyte zonation in two regulated estuarine areas in the Netherlands: Vegetation analysis and relationships with hydrological factors. Estuaries 22:657-668

Costanza R, dArge R, De Groot R, Farber S, Grasso M, Hannon B, Limburg K, Naeem S, Oneill RV, Paruelo J, Raskin RG, Sutton P, Van den Belt M (1997) The value of the world's ecosystem services and natural capital. Nature 387:253-260

De Klein CAM, Van Logtestijn RSP (1994) Denitrification in the top soil of managed grasslands in the Netherlands in relation to soil type and fertilizer level. Plant Soil 163:33-44

Driesprong AJ, Van Hees J, De Jong L (1998) Environmental impact assessment of the Haringvliet sluices. Directorate-General of Public Works and Water Management, Rotterdam, pp 119, (In Dutch)

Edmeades DC (2003) The long-term effects of manures and fertilisers on soil productivity and quality: a review. Nutr Cycl Agroecosyst 66:165-180

Eriksson PG, Svensson JM, Carrer GM (2003) Temporal changes and spatial variation of soil oxygen consump- 
tion, nitrification and denitrification rates in a tidal salt marsh of the Lagoon of Venice, Italy. Estuar Coast Shelf Sci 58:861-871

Flindt MR, Pardal JA, Lillebø AI, Martins I, Marques JC (1999) Nutrient cycling and plant dynamics in estuaries: A brief review. Acta Oecol 20:237-248

Greenwood DJ, Lemaire G, Gosse G, Cruz P, Draycott A, Neeteson JJ (1990) Decline in percentage N of C3 and C4 crops with increasing plant mass. Ann Bot 66:425436

Gribsholt B, Boschker HTS, Struyf E, Andersson M, Tramper A, De Brabandere L, Van Damme S, Brion N, Meire P, Dehairs F, Middelburg JJ, Heip CHR (2005) Nitrogen processing in a tidal freshwater marsh: A whole-ecosystem N-15 labeling study. Limnol Oceanogr 50:1945-1959

Groffman PM, Tiedje JM (1989) Denitrification in north temperate forest soils-spatial and temporal patterns at the landscape and seasonal scales. Soil Biol Biochem 21:613-620

Güsewell S, Koerselman W, Verhoeven JTA (2003) Biomass N:P ratios as indicators of nutrient limitation for plant populations in wetlands. Ecol Appl 13:372384

Haag D, Kaupenjohann M (2001) Landscape fate of nitrate fluxes and emissions in Central Europe. A critical review of concepts, data, and models for transport and retention. Agric Ecosyst Environ 86:1-21

Hawkins SJ, Gibbs PE, Pope ND, Burt GR, Chesman BS, Bray S, Proud SV, Spence SK, Southward AJ, Southward GA, Langston WJ (2002) Recovery of polluted ecosystems: the case for long-term studies. Mar Environ Res 54:215-222

Hefting MM (2003) Nitrogen transformation and retention in riparian buffer zones. Ph.D. thesis-Utrecht University, pp 200

Hefting MM, de Klein JJM (1998) Nitrogen removal in buffer strips along a lowland stream in the Netherlands: a pilot study. Environ Pollut 102:521-526

Hefting MM, Bobbink R, de Caluwe H (2003) Nitrous oxide emission and denitrification in chronically nitrate-loaded riparian buffer zones. J Environ Qual 32:1194-1203

Houba VJG, Van der Lee GEM, Novozamsky I, Walinga I (1989) Soil and plant analysis a series of syllabi. Wageningen Agricultural University, Wageningen

Howarth RW, Billen G, Swaney D, Townsend A, Jaworski N, Lajtha K, Downing JA, Elmgren R, Caraco NF, Jordan TE, Berendse F, Freney J, Kudeyarov V, Murdoch P, Zhao-Liang Z (1996) Regional nitrogen budgets and riverine $\mathrm{N} \& \mathrm{P}$ fluxes for the drainages to the North Atlantic Ocean: natural and human influences. Biogeochemistry 35:75-139

Ibanez C, Prat N, Canicio A (1996) Changes in the hydrology and sediment transport produced by large dams on the lower Ebro river and its estuary. Regul Rivers: Res Mgmt 12:51-62

Jordan TE, Correll DL, Whigham DF (1983) Nutrient flux in the Rhode river: tidal exchange of nutrients by brackish marshes. Estuar Coast Shelf Sci 17:651-667
Kalsbeek N (2004) Wijziging Besluit Beheer Haringvlietsluizen. Staatscourant 249:50, (In Dutch)

Kemp WM, Boynton WR, Adolf JE, Boesch DF, Boicourt WC, Brush G, Cornwell JC, Fisher TR, Glibert PM, Hagy JD, Harding LW, Houde ED, Kimmel DG, Miller WD, Newell RIE, Roman MR, Smith EM, Stevenson JC (2005) Eutrophication of Chesapeake Bay: historical trends and ecological interactions. Mar Ecol -Prog Ser 303:1-29

Koerselman W, Meuleman AFM (1996) The vegetation $\mathrm{N}: \mathrm{P}$ ratio: A new tool to detect the nature of nutrient limitation. J Appl Ecol 33:1441-1450

Morse JL, Megonigal JP, Walbridge MR (2004) Sediment nutrient accumulation and nutrient availability in two tidal freshwater marshes along the Mattaponi River, Virginia, USA. Biogeochemistry 69:175-206

Neubauer SC, Anderson IC, Neikirk BB (2005) Nitrogen cycling and ecosystem echanges in a Virginia tidal freshwater marsh. Estuaries 28:909-922

Nienhuis PH (1993) Nutrient Cycling and Foodwebs in Dutch Estuaries. Hydrobiologia 265:15-44

Odum EP (1984) The Mesocosm. BioScience 34:558-562

Olde Venterink H, Hummelink E, Van den Hoorn MW (2003) Denitrification potential of a river floodplain during flooding with nitrate-rich water: grasslands versus reedbeds. Biogeochemistry 65:233-244

Patrick Jr. WH, Reddy KR (1976) Nitrification-denitrification reactions in flooded soils and water bottoms: dependence on oxygen supply and ammonium diffusion. J Environ Qual 5:469-472

Phillips IR (1999) Nitrogen availability and sorption under alternating waterlogged and drying conditions. Commun Soil Sci Plan 30:1-20

Piesschaert F, Mertens J, Huybrechts W, Rache PD (2005) Early vegetation succession and management options on a brackish sediment dike. Ecol Eng 25:349-364

Reddy KR, Patrick Jr. WH (1984) Nitrogen transformations and loss in flooded soils and sediments. Crit Rev Environ Sci Technol 13:273-309

Ridgley MA, Rijsberman FR (1994) Multicriterion analysis and the evaluation of restoration policies for a Rhine estuary. Socio-Econ Planning Sci 28:19-32

Ryden JC, Skinner JH, Nixon DJ (1987) Soil core incubation system for the field measurement of denitrification using acetylene inhibition. Soil Biol Biochem 19:753-757

Rysgaard S, Thastum P, Dalsgaard T, Christensen PB, Sloth NP (1999) Effects of salinity on $\mathrm{NH}_{4}^{+}$adsorption capacity, nitrification, and denitrification in Danish estuarine sediments. Estuaries 22:21-30

Schipper LA, Cooper AB, Harfoot CG, Dyck WJ (1993) Regulators of denitrification in an organic riparian soil. Soil Biol Biochem 25:925-933

Schott W (2001) Nitrogen in agriculture as affected by the kind of fertilizer. II. Nitrogen in soil and plant. Phyton-Ann Rei Bot 41:159-167

Scott NA, Binkley D (1997) Foliage litter quality and annual net $\mathrm{N}$ mineralization: comparison across North American forest sites. Oecologia 111:151-159

Smit H, Smits R, Van der Velde G, Coops H (1997) Ecosystem responses in the Rhine-Meuse delta during 
two decades after enclosure and steps toward estuary restoration. Estuaries 20:504-520

Tappin AD (2002) An examination of the fluxes of nitrogen and phosphorus in temperate and tropical estuaries: current estimates and uncertainties. Estuar Coast Shelf Sci 55:885-901

Tenbrinke WBM, Dronkers J, Mulder JPM (1994) Fine Sediments in the Oosterschelde Tidal Basin Before and After Partial Closure. Hydrobiologia 283:41-56

Tönis IE, Stam JMT, Van de Graaf J (2002) Morphological changes of the Haringvliet estuary after closure in (1970). Coast Eng 44:191-203

Van Oorschot MMP (1994) Plant production, nutrient uptake and mineralization in river marginal wetlands: the impact of nutrient additions due to former landuse. In: Mitsch WJ (ed) Global Wetlands: Old World and New. Elsevier Science B.V., Amsterdam, pp 133150

Van Oorschot MMP, Van Gaalen N, Maltby E, Mockler N, Spink A, Verhoeven JTA (2000) Experimental manipulation of water levels in two French riverine grassland soils. Acta Oecol 21:49-62

Verhoeven JTA, Arheimer B, Yin CQ, Hefting MM (2006) Regional and global concerns over wetlands and water quality. Trends Ecol Evol 21:96-103

Verhoeven JTA, Bogaards H, Van Logtestijn RSP, Spink A (1998) Initial estimates of nutrient-related process rates in floodplains along modified rivers in the
Netherlands. In: Nienhuis PH, Leuven RSEW, Ragas AMJ (eds) New concepts for sustainable management of river basins. Backhuys Publishers, Leiden, pp 229 240

Verhoeven JTA, Maltby E, Schmitz MB (1990) Nitrogen and phosphorus mineralization in fens and bogs. $\mathrm{J}$ Ecol 78:713-726

Waring SA, Bremner JM (1964) Ammonium production in soil under waterlogged conditions as an index of nitrogen availability. Nature 201:951-952

Wassen MJ, Olde Venterink H, Lapshina ED, Tanneberger F (2005) Endangered plants persist under phosphorus limitation. Nature 437:547-550

Weeda EJ, Westra R, Westra C, Westra T (1994) Nederlandse oecologische flora, wilde planten en hun relaties 5. KNNV Uitgeverij, Utrecht, pp 400, (In Dutch)

Withagen L (2000) Delta 2000 Inventarisatie huidige situatie Deltawateren. Rijksinstituut voor Kust en Zee, Middelburg, pp 144, (In Dutch)

Yoshinari T, Knowles R (1976) Acetylene inhibition of nitrous oxide reduction by denitrifying bacteria. Biochem Biophys Res Commun 69:705-710

Zonneveld IS (1960) De Brabantse Biesbosch: een studie van bodem en vegetatie van een zoetwatergetijdendelta. Thesis Landbouwuniversiteit Wageningen, Wageningen, pp 395, (In Dutch) 